\title{
Ups and Downs of Sociology in Germany: 1968-1990
}

\section{“1968"}

Despite an economic prosperity phase that was only interrupted for a very short time, the 1960s saw political and cultural transformations (see in general Schildt et al. 2003). It was mainly adolescents and students who intended to start a revolt in 1968. The protest concerned many issues: The protest movement demanded a reform of education, and at the same time, the adolescents wanted to counterbalance the weakness of the parliamentary opposition through an Außerparlamentarische Opposition (APO, extra-parliamentary opposition). The movement also protested against the Vietnam War and for the civil rights movement in the USA. This, the West German protests had in common with the protests in the USA. For the West German 1968 generation, though, there was an additional decisive factor, namely the demand for a rigorous historical reappraisal of the Nazi regime. Many were opposed to the generation of their parents, who remained silent regarding the past. This became evident at school: Even history lessons often ended with the Weimar Republic and left out the Nazi era. The youth also demanded a condemnation of the numerous Nazi criminals who still held high-ranking positions. Many adolescents tried out alternative ways of life-they called for a more liberal sexuality as well as for women's emancipation and they held to post-materialist values that had already gained ground since the first halve of the 1960s. Moreover, 
the protest movement criticized the alliances of the German government with dictatorships. In particular, the movement wanted to prevent the German Emergency Acts drafted and implemented by the grand coalition in Germany, which also contained a restriction of basic constitutional rights (cf. Borowsky 1998, p. 14). And some feared that the Emergency Acts would mean a new Enabling Act.

Numerous events contributed to giving the protests a "dynamic of their own" (Siegfried 2018, p. 9): During a demonstration against the visit of the Shah Mohammed Reza Pahlavi, the student Benno Ohnesorg was shot dead by a policeman on June 2, 1967, at the West-Berlin opera. This led to a new dynamic and an expansion of the wave of protest. Hence, regarding the FRG, the year 1967 must be considered as "the actual date" of the student protests (Frei 2008, p. 118). The protests intensified when the policeman who had shot the student was acquitted. As a result, some media, such as Der Spiegel, took sides with the protesters (Frei 2008, pp. 126-127). In addition, in April 1968 the sociology student Rudi Dutschke, a well-known spokesman for the students, became victim of a serious assassination attempt. The press that belonged to the Springer publishing house, above all the populist newspapers BILD and WELT, was held responsible for the attempted assassination because it had been harassing the students since 1967 and had stylized Dutschke as the "public enemy number one." Thereafter, in many cities violent anti-Springer demonstrations were held. One month later, in May 1968, the government issued the controversial German Emergency Acts. The protests of the extra-parliamentary opposition (APO) were at their peak.

The situation was extremely tense, above all in Berlin and Frankfurt, but also in other cities. The core of the extra-parliamentary opposition (APO) was the Sozialistische Deutsche Studentenbund (SDS, Socialist German Student Union), which had been part of the Social Democratic Party (SPD) until 1960 (cf. Fichter and Lönnendonker 2018). The SDS had initially demanded equality of education, a reform of education, and democratization of the universities - decisions should not only be made by professors. In the late 1950s, it had also been actively opposed to the rearmament of Germany with nuclear weapons. The fact that the SDS was expelled from the SPD increased its attractiveness for critical, left-wing students to get involved in the activities of the SDS throughout the 1960s. Many of the 68ers were students of the social sciences and later were to become professors of sociology or political sciences (especially at the 
universities of Bielefeld, Bremen, Frankfurt, Göttingen, Hanover, Kassel, Münster, or Osnabrück).

The 1968 student movement brought sociology into the limelight. As a subject of study, sociology gained enormously in importance, which was connected with the growing need for social reflection in all areas of life. Parts of the SDS considered themselves to be part of the international labor movement; this was in particular the stance taken by the Marxist social scientist Wolfgang Abendroth in Marburg. The other part, which was closer to the Critical Theory of Frankfurt, saw itself more as part of the "emerging New Left" in Western Europe (Demirović 1999, p. 889), which distinguished itself from both the anti-communism of the West and the so-called real socialism of the East. The students read anarchist literature as well as Marx, Leon Trotsky, Rosa Luxemburg, Sigmund Freud, Wilhelm Reich, Georg Lukács, and authors of Critical Theory, whose writings were perceived as the "theoretical superstructure" of the protest movement (cf. Demirovic 1999, pp. 856-910). They were particularly enthusiastic about Herbert Marcuse and his books Der eindimensionale Mensch (1964, One-Dimensional Man, 1967) and Eros and Civilization (originally published in English, 1955), as well as pirate copies of the Dialectic of Enlightenment by Horkheimer and Adorno.

New journals and book series were established. The concept of culture was expanded. Pop culture and everyday culture underwent a revaluation; the then prevailing "legitimate culture" (Bourdieu) was revealed as a mere ideology and the separation between high and low culture was deconstructed. It was not only the "Summer of Love," but also the "long summer of theory" (Felsch 2015). The youth read and discussed much more than the generation before. According to the historian Detlef Siegfried, "1968" was also a "reading movement" that created a veritable "market for Marx" (Siegfried 2018, pp. 66-69). This benefited the publishing industry too. The production of sociological books increased. The Rowohlt publishing house with its series "rowohlts deutsche enzyklopädie" (rde) had dominated the academic reading public in the $1950 \mathrm{~s}$ and 1960s. It was being replaced by the so-called Suhrkamp-culture (especially the "Regenbogen-Reihe" (rainbow colored books) of the "edition Suhrkamp," later the famous "Suhrkamp Taschenbuch Wissenschaft" (stw)) since the beginning of the 1960s.

New journals were established, such as the social science journal Leviathan that was founded in 1973 (Blomert 2018) and the Soziologische Revue, founded in 1977, in which new books were presented and 
discussed (Hartmann 2018). Sociological topics were also discussed in the general public. Sociology had become a fashion, indeed an "existentialist" academic discipline, which was studied for reasons of political selfrealization and because of the possibility of discussing one's own social future against a theoretical background. "In the student movement, 'society' was not only discovered as an analytical category, but even more so as an existential category" (Bude 1994, p. 246). As studies from the 1960s show, most students of sociology as well as most participants of the student movement in general came from the milieus of those who experienced upward mobility (cf. Reimann and Kiefer 1969). As historiography has demonstrated on many occasions, in times of movements of cultural and social transformation, such as the avant-garde around 1920, those who are most anti-bourgeois are often themselves part of the bourgeoisie. This seems to be partly the case in Germany in 1968 too. Perhaps it was also a kind of class struggle between the upwardly mobile and the established, in which the social sciences were the "vehicle for the upwardly mobile" (Bude 1994, p. 249).

\section{Late Capitalism or Industrial Society?}

From April 8 to April 11, 1968, the 16th German Soziologentag was held in Frankfurt am Main on the theme of "Late capitalism or industrial society?" This was right at the heart of the wave of the student movement. Adorno and Ludwig von Friedeburg had prepared the congress, Dahrendorf had been president of the GSA since 1967. First and foremost, this Soziologentag was concerned with the question of whether the term "industrial society" or, rather, the term "late capitalism" would be better suited to capture the current social development. Adorno stated that the two were dialectically interwoven. This expressed precisely the contradictory character of contemporary society; "according to the state of its productive forces it is an industrial society, in its relations of production it is capitalism" (Adorno 1969, p. 18; emphasis in original).

However, this question was subsequently discussed only rarely. Instead, the controversy between Dahrendorf, Adorno, and other members of the Institute for Social Research flared up again. The contentious issues included the question of the necessity of domination, the connection between theory and critique, as well as the relationship between theory and practice (cf. Demirović 1999, pp. 837-844). In his lecture, Adorno made it clear that the capitalist system had spread in such a way that "no 
location outside of the gears can be obtained from which the spook can be named; the lever can only be applied to its own inconsistency" (Adorno 1969 , p. 25). Adorno did not see this as a renunciation of political practice. And it was the role of sociology to point out the inconsistencies. Adorno's hypothesis, however, was strongly refuted by Dahrendorf in his opening speech. He objected that an overly radical critique of society would not lead to emancipatory change, but would rather block the path to practice. Basically, however, the dispute was again about the confrontation between positivism and dialectical sociology, as some observers soon noticed (Demirović 1999, p. 844). Thus, during this Soziologentag, too, Critical Theory was attacked: "It was a matter of excluding it from sociology because of it being unscientific and not empirical, a matter of disavowing it politically as totalitarian or rejecting it as impractical and pessimistic" (Demirović 1999, p. 849).

Dahrendorf soon resigned from his presidential office in 1969 because he changed to the sphere of federal politics. First, he became a deputy Secretary of Foreign Relations within the federal government, followed by his membership in the European Commission 1970-1974. He later became director of the London School of Economics (1974-1984) and professor of Social Sciences at the University of Konstanz again. ${ }^{1}$

\section{Critical Theory and the Protests of “1968”}

The Soziologentag that took place in April 1968 was experienced as a disappointment by many students. There was a partial alienation between the students and sociology, and the relation to Critical Theory was ambivalent. At the beginning of the 1968 movement, Critical Theory at first seemed to remain no longer "just" theory, but seemed to become a "practical" venture. In the early days of the protests, the Frankfurt School, especially Adorno, Marcuse, and Habermas, had become political and moral authorities with a public impact and they had become important suppliers of theory for the revolt of the youth. There were numerous attempts to derive a political practice from Critical Theory. In the further course of the protests, however, the relation between the students and Critical Theory ended in a disagreement. There were diverging assessments

\footnotetext{
${ }^{1} \mathrm{He}$ was in the 1960s co-founder and has already been professor of the University of Konstanz, see Chap. 3. From 1987 to 1997 he was Warden of St Antony's College at the University of Oxford.
} 
of theory and practice. Adorno warned against pointless actionism. Habermas even accused parts of the student movement of being "left fascists" because of their provocation of manifest violence (Habermas 2008, p. 148; Demirović 1999, p. 920). The accusation of "Leftist Fascism" was undifferentiated and was taken up all too readily by the conservative forces and the government (cf. Abendroth 1968, p. 133). An expert on Critical Theory, Alex Demirović (1999, p. 934), has summarized Habermas' position as follows: Habermas accused the students of completely misinterpreting the social situation. The situation was not revolutionary, although many students believed it was. In Habermas' view they suffered from a delusion; after all, neither did the broad masses of the population share the students' indignation, nor was there any unity between students and workers, so that it was only a Scheinrevolution (pseudo-revolution). Since then "Habermas's name [...] was taboo because of his criticism of tendencies toward a 'Leftist Fascism' in the student movement. Whoever mentioned his name, nevertheless, as I did, had to reckon with the same fate of being shunned. In other classes, the exegesis of Marx's texts dominated over all substantial problems" (Joas 2005, p. 163).

The students, on the one hand, began to disrupt the lectures and wanted to politicize the universities, while Adorno, on the other hand, emphasized the autonomy of academia as an area of freedom. Finally, activists accused Critical Theory of being authoritarian and elitist itself. They called for a reorganization of the Institute for Social Research so that students could organize their studies themselves. Finally, in December 1968, students occupied Adorno's Sociological Seminar (Demirović 1999, pp. 941-946). Adorno called the police, who cleared the Institute. He criticized the "pure nonconceptual practicism" of the students (Demirovic 1999, p. 916). In the further course of events, the students demanded a public self-criticism of Adorno. In a lecture with 1000 listeners, they shouted "Nieder mit dem Denunzianten-Ordinarius" ("Down with the denunciator-professor"). Female students from the Basisgruppe Soziologie ("action group sociology," a political student's group), with bared breasts, tried to kiss Adorno (Demirovic 1999, p. 947). On the blackboard they wrote: "Wer nur den lieben Adorno läßt walten, der wird den Kapitalismus ein Leben lang erhalten" ("Whoever lets dear Adorno rule, will keep capitalism alive") (Siegfried 2018, p. 97). Adorno left the lecture hall and cancelled the lecture until further notice. Four months later he died of a heart attack. But Critical Theory continued to have an 
effect elsewhere. It had a broad impact, be it in other disciplines such as education, in shared student flats, or in the feuilleton or radio (cf. Boll 2004, pp. 159-187).

The protest movement was at its peak in May 1968, but at the same time its "decay" started to become apparent (see Borowsky 1998, p. 20). Neither could the trade unions be persuaded to go on strike, nor could a broader mass of people be won over to a far-reaching change. After the attempted assassination of Dutschke, the leftist movement had begun to split up more and more into different groups. Some parts radicalized and founded the terrorist organizations " 2 June Movement" (that carried out bank robberies, kidnappings, and assassination attempts until 1980, and especially the "Red Army Faction" (RAF, more on that below). In 1970, the SDS disbanded. The larger part of the APO set out on the "long march through the institutions" propagated by Dutschke. What was meant by this was to bring about social change from within, through the influence in institutions. The APO continued to live on not only in the institutions, but also in the social movements of the 1970s and 1980s, the women's movement, anti-nuclear movement, environmental movement, and peace movement, as well as in the political party Die Grünen (The Greens), founded in 1980 .

\section{New Research Institutes}

As of the mid-1960s, numerous new research institutes were founded. They were, among other things, concerned with peace research, education, and Eastern Europe, although most of them focused on industry and labor. In Munich, for example, the Institut für Sozialwissenschaftliche Forschung (ISF, Institute for Social Science Research) was founded in 1965 (cf. Sauer 2018), the Institut für Arbeitsmarkt- und Berufsforschung (Institute for Employment Research) in Nuremberg in 1967, the Institut für Marxistische Studien und Forschungen (IMSF, Institute for Marxist Studies and Research) in Frankfurt and the Soziologische Forschungsinstitut (SOFI, Sociological Research Institute) in Göttingen both in 1968 (cf. Baethge and Schumann 2018; Brückweh 2019), 1969 the Wissenschaftszentrum Berlin (WZB, Berlin Social Science Center) (cf. Knie and Simon 2018). While the topics of work and industry were on the decline at the beginning of the 1960s, they gained importance again at the end of the 1960s due to a rise in unemployment. In addition, the SPD-led government that was newly elected in 1969 promoted and funded social 
research and hoped to gain insights into long-term technical and economic change (cf. Kern 1982, pp. 239-246). This was beneficial for empirical social research in general. In 1970, a study was conducted at the SOFI in Göttingen which led to a veritable renaissance of and to an "independent profile of German industrial sociology" (Schmidt 1980, p. 272): Industriearbeit und Arbeiterbewußtsein (Industrial Work and Worker Consciousness) by Horst Kern and Michael Schumann. The book dealt with the question of the interrelation of technology, development, new forms of work, and the consciousness of the workers.

Initiated by members of the German Bundestag, the Wissenschaftszentrum Berlin (WZB, Berlin Social Science Center) was founded in 1969. It was intended to provide a counterweight to Marxist currents and to serve as a center for social science planning and policy advice (cf. Knie and Simon 2018).

\section{New Universities}

The number of students had increased immensely since the 1950s. This also increased the need to establish new universities and to reform the Higher Education system (Kenkmann 2003, pp. 415-423; Rohstock 2010). Moreover, Germany also wanted to remain competitive and not lose ground to the USA or the USSR in the field of science and research. The goal was "research and mass education" (Wehrs 2014, p. 41; emphasis in original). The expansion of education brought with it the establishment of numerous new universities and universities of applied sciences (Fachhochschulen). In 1962, universities were founded in Bochum and Regensburg. In addition, the so-called reform universities were established: In 1966 a university was founded in Konstanz, in 1969 in Bielefeld, and in 1971 in Bremen. As the new universities needed personnel, the number of professorships and other academic positions increased. "In the following decades, the habitus of the professoriate became more informal and permissive. Several of the [student] movement's spokespersons became professors at a very young age because the expansion of the HE [Higher Education] system needed personnel. Thus the professoriate moved politically to the left for the first time since 1848 revolution" (Duller et al. 2019, p. 77). Often these new positions were no longer powerful and almost independent chairs, but less well-equipped professorships, and in some cases the assistants and students had more and more say in the decision-making processes. However, the increase in participation 
also meant more work in administration and commissions, at the expense of research and career. "Many a young post-Sixties sociologist who believed in democracy and decision participation got caught up in the jungle of committees and paragraphs, only to reemerge too late for the pursuit of sociological excellence and perhaps even the advance of a career" (Knorr-Cetina 2005, p. 191).

The founding of new universities, the "boom in education" (Raphael 2003 , p. 218; Kenkmann 2003), the opening of the universities to young people from the lower social classes, and the general political mood benefited most social sciences, including the institutionalization of sociology. In 1960, it was still possible to study sociology as a major at around 20 universities. By 1970, this number had increased to 60 universities. The number of sociology students increased, reaching its peak in the period 1969-1974 (Siefer and Abrahams 1994, p. 293). The number of classes also increased in line with the number of students (cf. Weischer 2004, pp. 247-250).

Society expected sociology to provide interpretations and advice. This also affected the market for and the style of sociological books. There was a "great demand" for social science literature, encouraged by the "growing educated knowledge" (Raphael 2003, p. 222). Publishers hoped to profit from the sociological diagnoses and promoted the spread of sociology, especially in the form of paperbacks. Some historians of sociology in Germany, such as Oliver Römer (2019), even assume that "1968" was only made possible by a sociology strengthened by the publishers. In any case, sociologists increasingly composed books that explicitly addressed a broader public (cf. Neun 2018). At the same time, the expansion of sociology at the universities led to the founding of new journals (see Römer 2018, p. 496): in 1972 the Zeitschrift für Soziologie and the already mentioned journal Leviathan, in 1973 the journal Soziologie of the GSA, and in 1978 the Soziologische Revue). Sociology was now firmly established at the universities and had consolidated as an academic subject. Similar to the field of history, the expansion and growth led to a decline of the weight of "personal acquaintance" and of the "influence of individual powerful professors" and thus to a weakening of the "tendency towards conformity" (Raphael 2003, p. 219). This was another element on the path to a further pluralization of the discipline.

When the new universities were founded, some experimentation was also undertaken (cf. Kruse and Strulik 2019). The sociologists Dahrendorf and Schelsky were the leading figures in this. Dahrendorf was involved in 
the planning of the University of Konstanz in 1966. There he wanted to establish a pure research university, a "Princeton at the Lake of Konstanz." A novelty in Konstanz was the establishment of a Faculty of Social Sciences.

The foundation of Bielefeld University in 1969 was based on plans by Schelsky. He advocated a research university too. Every second year was to be a sabbatical year. In addition, interdisciplinary exchange was to be massively promoted. The dominant model was Wilhelm Humboldt's educational ideal, that is, to regard education not primarily as training, but as the development of personality and self-development of the person. In 1970, Schelsky became professor in Bielefeld. However, as the university did not develop as he had intended and as the ministry of education and cultural affairs, too, had reservations regarding his reform ideas and the special treatment of a university, he left Bielefeld disappointed after three years (cf. Bock 1986).

A unique feature of Bielefeld (to this day) was the establishment of a faculty that comprised only sociology, as was pushed by Schelsky, and which heralded a new level of professionalization (cf. Kruse and Strulik 2019). The founding of the Zeitschrift für Soziologie was also started by people from the faculty. "Bielefeld had sociology in its genes, one might say, and this translated into the faculty's considerable size, rich course offerings, and manifold activities," remembers Karin Knorr-Cetina (2005, p. 189). The Faculty of Sociology in Bielefeld was largely staffed by sympathizers of Schelsky. One of these sociologists, who was strongly supported by Schelsky and who received a professorship at the newly founded faculty, was Niklas Luhmann.

\section{The Habermas-Luhmann Debate}

Jürgen Habermas and Niklas Luhmann both belong to the same generation. Both developed the basic principles of their grand theories in the 1970s; in the early 1980s, their respective major work Soziale Systeme (Luhmann 1984, Social Systems) and Theorie deskommunikativen Handelns (Habermas 1981, The Theory of Communicative Action) emerged from these theories.

Luhmann was initially an administrative official. Thanks to a scholarship to Harvard he had met Talcott Parsons in 1960 (cf. Horster 2005, p. 33). He was particularly interested in Parsons' structural functionalism. After the encounter with Parsons, Luhmann wrote a study on the sociology of organizations, which applied Parsons' theory to organizations and which 
at the time was highly innovative for this field of sociology. Schelsky invited Luhmann to give a lecture at the Social Research Center Dortmund and began to support him. Luhmann was given a position for sociological theory and sociology of law at the Social Research Center-or rather: $\mathrm{He}$ was "parked" in this position, as Luhmann himself described it (cf. Horster 2005 , p. 38). In 1966, within one year, Luhmann completed his doctorate and habilitation with Dieter Claessens and Helmut Schelsky. In the meantime, he was already initiated into the plans for the foundation of Bielefeld University. Luhmann, too, gave a lecture at the 1968 Soziologentag. "Moderne Systemtheorien als Form gesamtgesellschaftlicher Analyse" ("Modern Systems Theories as a Form of Analysis of Society as a Whole") was the title of his lecture, which was only poorly attended. Initially, he was perceived only as a sociologist of organizations, of law and politics, not as a theorist, although he had already published several articles on the theory of social systems in journals in the late 1960s. ${ }^{2}$

The recognition of Luhmann as an independent theorist only really gained momentum through the so-called Habermas-Luhmann debate, especially through the book Theorie der Gesellschaft oder Sozialtechnologie (1971, Theory of Society or Social Technology), which emerged from this debate (Joas and Knöbl 2009, p. 251). The controversy was also a consequence of the students' disagreement with Critical Theory. After the eviction of the students from the Institute for Social Research by the police, initiated by Adorno, and the accusation of "Leftist Fascism" made by Habermas, many students were in search of theoretical alternatives. "In 1969, when students attempted to annul Critical Theory with Luhmann's systems theory, this developed into a seminar to which Habermas invited Luhmann" (Rammstedt 1999, p. 18).

Habermas had a fast career. As with most major theories originating in Germany, a close connection between sociology and philosophy can be found in his work (cf. Müller-Doohm 2014, pp. 55-96; Yos 2019). He wrote his doctoral thesis on the idealistic philosopher Friedrich Wilhelm Joseph Schelling (1775-1854) under Erich Rothacker (1888-1965), a philosopher and former NSDAP member. At the young age of 24, Habermas became known to a wider public because of a critique of the

\footnotetext{
${ }^{2}$ Karl Hermann Tjaden (1935-2021), professor in Marburg, since 1974 in Kassel, disciple of Abendroth, was one of the first who recognized the theoretical weight of systemstheoretical approaches and dedicated to them a criticism unsurpassed until today (Tjaden 1969; Tjaden 1971).
} 
philosopher Martin Heidegger (1889-1976). This also marked the beginning of his career as a public intellectual (Müller-Doohm 2014, pp. 87-96; Yos 2019, pp. 102-112). Among his intellectual influences at that time were hermeneutics and Marxism as well as democratic liberalism (Joas and Knöbl 2009, pp. 202-207); later on he was also influenced by pragmatism, philosophy of language, and developmental psychology. In the 1950s, Habermas became a faculty member at the Institute for Social Research in Frankfurt. In 1961, still without a habilitation, he was appointed to a professorship of philosophy in Heidelberg. Since he seemed too Marxist to Horkheimer, Habermas could not habilitate in Frankfurt (Joas and Knöbl 2009, p. 201). Horkheimer tried more and more to detach himself and the Institute from Marxism. For Horkheimer, Habermas was too leftist. After unsuccessful inquiries with Schelsky, Plessner, and Arnold Bergstraesser, Habermas finally habilitated in 1961 with the Marxist social scientist Wolfgang Abendroth in Marburg (MüllerDoohm 2014,p. 129). The habilitation thesis dealt with the Strukturwandel der Öffentlichkeit (The Structural Transformation of the Public Sphere, published in 1962). In 1964, Habermas followed Horkheimer, who had refused to habilitate him, as professor of sociology and philosophy in Frankfurt. Increasingly, Habermas then began to stylize himself as a representative of Critical Theory (Joas and Knöbl 2009, p. 208) and took the first steps toward his seminal Theory of Communicative Action.

The controversy between Habermas and Luhmann revolved primarily around the issue of social criticism. Habermas' accusation against Luhmann was that systems theory assumed the function of legitimizing domination. Instead of solving political and practical questions with the help of discourse, systems theory recommended a social-technological analysis: "This theory represents, so to speak, the high form of a technocratic mind, which today allows defining practical questions from the very beginning as technical ones, thus withdrawing them from public and informal discussion" (Habermas 1971, p. 145). Luhmann, on the other hand, accused Habermas of simplifying the complexity of society by drawing contrasts that were too plain-such as those between practice and technology (Luhmann 1971, p. 399).

The fact that the students had called for an engagement with the theory of Luhmann was further evidence of the alienation between Habermas and the left-wing students. In Frankfurt he remained unpopular and was increasingly detested by the students because of his accusing them of being "Leftist Fascists." In 1971, he decided to go to Starnberg as 
co-director of the renowned Max-Planck-Institut zur Erforschung der Lebensbedingungen der wissenschaftlich-technischen Welt (Max Planck Institute for the Study of the Scientific-Technical World). As in the Positivism Dispute, the Habermas-Luhmann controversy again showed a tendency for theoretical controversies to move further and further away from the analysis of concrete social conditions.

\section{The Debate on Theory Comparison}

The Habermas-Luhmann controversy left a deep dissatisfaction among sociologists and the public. Until the end of the 1980s, it led to new discussions about the relationship between theory and practice and to debates about the use of sociological knowledge (see Beck and Bonß 1989; Wingens 1988). In the sociological field, the controversy had also led to further divisions and confrontations. Now Habermasians and Luhmannians were facing each other. Further positions also emerged.

The sociologists were irritated by the multitude of available theories and positions. The 17th Soziologentag, held in Kassel in 1974, was intended to provide some clarification. The meeting was to deal with a comparison between leading theoretical positions. This led to a further debate that did not come to an end until the early 1980s. The comparison of the theories was accompanied by the expectation of transforming diversity into a "productive pluralism" and of establishing a "discursive unity of sociology" (Greshoff 2010, pp. 182-185). As with the positivism dispute, an attempt should be made to objectivize and "scientize" (verwissenschaftlichen) the intellectual struggles.

The following theoretical positions were represented: Habermas presented his theory of communicative action, Luhmann the functionalist systems theory, Joachim Matthes (1930-2009) advocated an interactionist phenomenological theory, Karl-Dieter Opp ( $\left.{ }^{*} 1937\right)$ represented the theoretical-behavioral approach, and Karl Hermann Tjaden stood for a historical-materialist theory. As a preparation, all of them had received a discussion paper on the topic of "evolution/social change." Not everyone felt represented; in particular, a decidedly critical sociology was missing and it was questioned why evolution was discussed instead of revolution (see the critiques in Krysmanski et al. 1975). No women were involved in the debate. For a long time, female sociologists were not actively involved in the Soziologentage, not even in the "debate on theory comparison" (Theorienvergleichsdebatte). Only after the founding of the section 
"Women's Studies in the Social Sciences" in the GSA in 1979, the number of female lecturers at the Soziologentag increased. However, overall it can be said that despite the expansion of the personnel in the 1970s, a very strong dominance of male sociologists continued to prevail (Vogel 2006, p. 11).

The aim of the Soziologentag - namely to order and systematize the pluralism of theories and to transform it into a productive pluralism based on a sociological division of labor-was not fulfilled. Nevertheless, the debate resulted in the establishment of the GSA section on "Sociological Theory," founded in 1980.

The failure and lack of consequences of the comparison of theories led to a growing mood of crisis in sociology (cf. Leendertz 2010, pp. 52-55). In the USA, Alvin Gouldner had already invoked The Coming Crisis of Western Sociology (1970). Similar to Gouldner, sociologists in Germany criticized that sociology did not face the new social challenges and that it contributed to the stabilization of the unjust social order. The criticism was foremost directed at the board of the GSA. The board was said to have fled all too readily from concrete social developments into the abstraction of a comparison of theories in order to avoid a necessary politicization (Krysmanski et al. 1975). Critics challenged, above all, the fact that official sociology had not done enough to oppose the "occupational bans" issued in 1972, which in practice mainly affected people from the left spectrum, most of them from the Deutsche Kommunistische Partei (DKP), founded in 1968 (a reconstitution of the KPD, banned in 1956), and also members of the Deutsche Friedensgesellschaft (German Peace Society) and the Vereinigung der Verfolgten des Naziregimes-Bund der Antifaschistinnen und Antifaschisten (Association of Persecutees of the Nazi Regime/ Federation of Antifascists).

While left-wing sociologists criticized that sociology did not deal enough with its own society and the obvious social antagonisms (Krysmanski et al. 1975), critical voices were also raised from the rightwing spectrum. The right-wing critics claimed that the crisis of sociology was mainly caused by the Americanization as well as by the critical orientation of the 1968 generation and its "revolutionary theology" (Eisermann 1976). Even Critical Rationalism was "too critical" for these "anti-critics" (Mongardini 1976, p. 59). All in all, there was an ideological split between left-wing and conservative sociologists, which often reached as far as into the sociological institutes, poisoning the social climate there, and in some places continuing up until the 1990s as for example in Bremen. 


\section{ANTI-SOCIOLOGY}

Well-known and leading sociologists, such as Helmut Schelsky and Friedrich Tenbruck, an expert on Max Weber who taught in Tübingen, saw sociology in such a deep crisis that they openly and clearly distanced themselves from it. They presented themselves as "anti-sociologists" (Schelsky 1981). Paradoxically, they saw the crisis precisely in the "boom" of sociology, in the rise of the social importance of the subject due to the student movement and the left (cf. Rehberg 2010, p. 218). The "boom" was also evident in the media and the educational institutions, which increasingly adopted sociological categories of interpretation. Other academic disciplines, such as history, integrated sociological knowledge too (cf. Weischer 2004, pp. 246-249). A veritable popularization of the sociological vocabulary occurred; a popularization that was received with great skepticism by the "anti-sociologists."

In the book Die Arbeit tun die anderen. Klassenkampf und Priesterherrschaft der Intellektuellen ([1975] 1977; the title literally translates as The Others do the Work. Class Struggle and Hierocracy of the Intellectuals) Schelsky warned vehemently of the "time-determining effect of all sociology," the "dissolution of the person" that is sometimes only understood in a functional manner as a role resulting from a person's social conditions (Schelsky 1977, p. 359). Moreover, he feared that sociology would increasingly become a kind of "new social religion" and sociologists a "class of salvation-promising producers of meaning" (Schelsky 1977, p. 399). In addition to the critique of sociology, there was also the critique of public intellectuals - an old topos of conservative anti-sociology, which Émile Durkheim had already been exposed to in the Dreyfus Affair. And paradoxically, Schelsky was himself one of the "star-intellectuals" of that time (Schäfer 2015) who himself once had successfully promoted sociology as an academic discipline.

Friedrich Tenbruck, too, feared the sociological "abolition of man as an acting being": According to Tenbruck, sociology increasingly regarded humans either as class subjects or as role bearers only, but would no longer consider their individuality (Tenbruck 1984, p. 49). His criticism was directed against Marxist currents, the Frankfurt School, and role theory, as well as against structural functionalism, the latter being perceived as overly influential. Tenbruck perceived these directions as the mainstream of sociology. His counter-program was a cultural sociology following Max Weber and Georg Simmel, which was intended to distinguish itself also 
institutionally from the mainstream of the German Sociological Association. However, contrary to what he had expected (in institutional terms), there was no counter-movement to the GSA. Nevertheless, the "Cultural Sociology" section was established and founded within the GSA, which, in its understanding of cultural sociology as a general sociology, was substantially influenced by Tenbruck (cf. Albrecht and Moebius 2014).

Basically, the anti-sociology of Schelsky and Tenbruck fizzled out relatively soon. From a sociological point of view, Schelsky's and Tenbruck's rejection and criticism was also an attempt to secure their own position and their sociological privilege of interpretation in the sociological field. In essence, therefore, the critique was not so much directed against sociology in general; the critique was rather an expression of a struggle in the sociological field, or to put it in Bourdieu's terms, the critique was primarily directed "against certain competing theoretical concepts" (Rehberg 2010 , p. 246). From the perspective of the "anti-sociologists," sociology seemed to be in crisis. Despite different motivations, they shared this critical view of sociology with some of their left-wing colleagues. But such debates were and are relevant to sociology. After all, can these debates and critiques of sociology not be interpreted as processes of self-understanding within sociology as well, which represented a further step in self-reflection and the development of sociology?

\section{Social Crises}

The sociologists debated their subject and observed the disciplinary crises in different ways. By discussing and criticizing their academic discipline, they occasionally lost sight of their real subject: society and its problems. The society of the FRG as a whole went through several crises in the mid-1970s. The political change in 1969 had initially caused a certain euphoria and an optimistic mood: ${ }^{3}$ In March 1969, the FRG got a new Bundespräsident (Federal President), Gustav Heinemann, who was the first in this office to have campaigned against rearmament and who had shown sympathy for the student movement. He also criticized the confrontation between Marxism and Christianity, propagated by Adenauer. For, according to Heinemann, Jesus did not die in opposition to Marx, but for all of us.

\footnotetext{
${ }^{3}$ For the here described historical processes I especially refer to Wolfrum (2007a).
} 
In September 1969, a social-liberal government came to power for the first time in the history of the FRG. Willy Brandt of the SPD, who had been in exile and a resistance fighter, became Chancellor. Initially, for many Germans, the political change proved that a strong democratic mindset was taking root. The expansion of the welfare state, legal liberalization, and more opportunities for participation gave hope for a positive change in society. The new Chancellor Brandt was widely associated with the political style and charisma of John F. Kennedy (Wolfrum 2006c, p. 315). In particular, Brandt's genuflection in front of the memorial of the former Warsaw Ghetto (Kniefall von Warschau) symbolized the new Ostpolitik and a new self-image of the government. A policy of détente and reconciliation with the East was sought. In 1971, Brandt was awarded the Nobel Peace Prize. After the chancellorship of Brandt, the central event of the policy of détente was the signing of the CSCE Charter (Helsinki Accords of the Conference on Security and Co-operation in Europe) in 1975. However, by the end of the 1970s the policy of détente had come to an end. The Soviet Red Army invaded Afghanistan and Ronald Reagan pushed the military armament of the USA. The Cold War reached yet another peak.

With regards to domestic policy, the situation in the FRG was by no means settled. Germany was afflicted by terrorism. During the 1972 Olympic Games in Munich, members of the Israeli team were murdered by Palestinian terrorists. However, it was above all the internal German terrorism of the Rote Armee Fraktion (RAF, Red Army Faction or BaaderMeinhof Group), which, alongside the economic crisis, became the greatest challenge for the Federal Republic. The terrorism of the RAF reached back into the 1960s, to the murder of Benno Ohnesorg (cf. Terhoeven 2017), and reached its "peak" in autumn 1977, the so-called Deutscher Herbst ("German Autumn") (Wolfrum 2007a, p. 13). Through numerous murders of high-ranking figures from the judiciary, politics, and business, the RAF sought to obtain the release of its imprisoned founders Andreas Baader, Gudrun Ensslin, and Jan-Carl Raspe. Palestinian terrorists supported this demand by hijacking a plane in October 1977. However, the newly formed police counter-terrorist unit GSG 9 succeeded in freeing the passengers. Subsequently, the RAF prisoners committed suicide. The "German Autumn" was overcome, but society was frightened and "polarized" (Wolfrum 2007a, p. 13). Some even wished to reintroduce the death penalty, while others saw the rule of law in jeopardy because of the numerous internal security measures. 
In domestic politics, a turmoil had already taken place in 1974. Brandt resigned as Chancellor. The reason for this was that the Chancellor's personal advisor, Günter Guillaume, was identified as a spy of the German Democratic Republic (GDR). Even though Brandt could not be held responsible for this negligence of the secret services, he assumed political responsibility with his resignation. His successor as Chancellor in 1974 was Helmut Schmidt, who first had to face the struggle against terror.

Another problem that Germany faced in the mid-1970s was the 1973 oil crisis. The global economy fell into a state of emergency. For Germany, too, it became clear: The Wirtschaftswunder (economic miracle) had come to its real end. The post-war "boom" was over (Doering-Manteuffel and Raphael 2012). The market of the automotive industry collapsed. However, the textile industry, shipbuilding, and the steel industry were particularly affected (Abelshauser 2011, p. 392). Nevertheless, the crisis also revealed that Germany had developed into an important global player over the previous years and was one of the most powerful industrial nations (Abelshauser 2011, p. 396). In line with the growing international significance, international transfer payments, for example the contribution to the UN or the expenditure on development aid, had increased "in the 1970s from 8 to 20.1 billion DM [German mark; S.M.]" (Abelshauser 2011 , p. 397). Expenditure on the further development of the welfare state, such as pension reform, minimum social security benefits, or the expansion of health insurance, also entailed high costs.

The crisis had a particular impact on employment. The unemployment rate rose from $0.7 \%$ to $2.5 \%$; one million people were out of work. Measured by current standards, this may seem little, but for the former FRG it was an enormous number. The recruitment of foreign Gastarbeiter (guest workers) was stopped. Yet a partial change of mentality also occurred. The exploitation of nature, the waste of resources, and consumption at the expense of the so-called Third World increasingly became a concern. According to Habermas, "late capitalism" entered into a "crisis of legitimization" (1973).

An "ecological awareness" increasingly developed. In 1972, the Club of Rome, an association of scientists and industrialists, urged to consider the limits of growth and warned of a further overexploitation of natural resources. In addition to the peace movement and the women's movement, various environmental movements then emerged, in which around two million Germans were involved by the end of the 1970s (Wolfrum 2007a, p. 14). The environmental movements gained in popularity, 
especially through the increasing criticism of nuclear power plants. A separate anti-nuclear movement emerged, which-particularly as a result of the Three Mile Island accident (1979) and the Chernobyl disaster (1986) - grew in the 1980s and 1990s and contributed to the founding of the political party Die Grïnen (The Greens). The movement's greatest success was the decision taken in 2000 to phase out nuclear power.

The political and economic crises fueled a feeling of insecurity among Germans. Some had lost their utopias of "1968." Many were seeking new providers of meaning and found them in the emerging esotericism and psycho-boom or in the fitness studios that were appearing everywhere (Wolfrum 2007a, p. 107). Identity search was the big issue. For some, the search began with a romantic transfiguration of the past. This became evident, for example, in fashion, where retro-chic appeared, in architecture with the rebuilding of many medieval town centers, in literature that focused on homeland (Heimat) themes, and a growing interest in local history (Wolfrum 2007a, p. 108). The identity of the Germans was also shaken by the Nazi past, as the US-American TV series "Holocaust" revealed in an unvarnished way. The stories portrayed in the series-on the one hand, the terrible fate of the Jewish family Weiß and on the other, the plot from the perspective of a perpetrator-shocked many people. The series made the crimes of the Germans become visible to many and contributed significantly to the development of a culture of remembrance in Germany-but only now, more than 30 years after these crimes had been committed.

\section{Differentiation and New (Qualitative) Methods in the “Great Age” of Empirical Social Research}

In retrospect, the much-lamented crisis of sociology was interpreted as the inability of sociology to deal with the aforementioned social transformation processes and crises. But some sociologists also saw this as a challenge. It eventually led to a stronger focus of sociology in West Germany on specific problems, very concrete questions, and empirical research on industry, labor, education, and urban planning. Empirical social research and so-called special sociologies or hyphen-sociologies, such as industrial sociology, therefore regained importance. By contrast, discussions on the theory of science, such as the Positivism Dispute, receded into the background for sociologists in general (cf. Schmidt 1980, p. 272). 
The 1970s led to a further specialization of sociology, which was reflected, among other things, in the founding of new chairs on specific topics and the establishment of new sections in the GSA (for the genesis of the sections see Borggräfe 2018): Newly founded sections of the GSA from the 1970s onwards were concerned with methods (1971), education (1971), family and youth (1971), religion (1971), cities and urbanism (1971), Eastern Europe (1971), social indicators (1972), industry (1972), developing countries (1973), law (1973), medicine (1973), science (1974), language (1977), social problems (1977), social policy (1979), and women's studies (1979). New developments took place at the higher level of the organization too: In 1976, the Berufsverband deutscher Soziologinnen und Soziologen (Professional Association of German Sociologists) was founded, which in particular represents sociologists on the free market outside of academia.

As Christoph Weischer (2004) has shown in detail in his comprehensive study on the history of empirical social research in Germany, "three guiding principles" characterized social research in the 1970s: "improvement," "emancipation," and "scientification" (Weischer 2004, pp. 321-338). With reference to the guiding principle of "improvement," social research was seen in the light of its social technological application. This involved planning and evaluating as well as producing social reports with the help of social research and social indicators research. Against the background of this guiding principle, sociologists such as Fritz Scharpf $\left({ }^{*} 1935\right)$ and Renate Mayntz contributed significantly to the expansion and reflection of sociological policy advice and policy research. They pleaded for "active political control of social development" (Leendertz 2010, pp. 70-71). The ability to control and plan social processes was also the central concern of the GSA in the mid-1970s and was the key issue at the 1976 Soziologentag (cf. Borggräfe 2018 , p. 878). Many considered this kind of empirical research a nonideological science, but failed to reflect upon its inherent ideological character. The guiding principle of "emancipation" (Weischer 2004, pp. 330-336) aimed to initiate critical and emancipatory social processes through social research. Central to this was industrial sociology, which was based on the theory of Marx or Critical Theory, and on concepts for the "humanization of work" (Weischer 2004, p. 331, p. 334). It often applied interpretative or participatory methods. The third guiding principle, "scientification," had been particularly formative for the beginning of empirical social research after 1945 and consisted, in accordance with 
the perspective of René König, in establishing social research as the foundation of sociology as an academic discipline. Empirical social research became increasingly important in the 1970s and was successfully institutionalized. Training in methods grew immensely. The number of textbooks and courses on methods increased by a factor of 20 (Weischer 2004, pp. 347-355). Standardization, canonization, and specialization took place. Some also described the period up to the end of the 1970s as the "great era of empirical social research" (Weischer 2004, pp. 235-366).

Despite the criticism of empirical social research, as was formulated especially from the perspective of Critical Theory, it was institutionalized and expanded in the study programs at the universities. Above all, empirical social research experienced a "boom" at institutions beyond the universities (Weischer 2004, pp. 250-251). In particular, research related to social democratic reform policy was funded (cf. Kern 1982, p. 243). Thus, social research in this period was more "externally driven" than in the 1950s and 1960s (Weischer 2004, p. 360). The number of empirically oriented papers in journals also increased. Along with the institutional success of empirical social research, expectations and hopes increased that it could be applied directly and beneficially in a socio-technological sense (Weischer 2004, p. 321).

The 1970s saw not only a boom in social research, but also a change in the field of empirical social research: "Qualitative" research methods (cf. Ploder 2018) were established in the field, which — to this day-are fiercely contested by some representatives of quantitative methods (cf. Weischer 2004, pp. 400-431). Quantitative methods had long been regarded as the ideal of the development of methods. Not only were they increasingly applied, but in the course of this they were also increasingly refined. In certain locations, a veritable cult of methods emerged, in which practical application receded into the background in favor of a methodtechnocratism. By its representatives, quantitative social research was closely and positively associated with progress, modernization, and rationalization. If it was related to theories, then, as Weischer (2004, p. 357) points out, it was initially linked to functionalist approaches, and today especially to concepts of methodological individualism. Current representatives refer to it as an "empirical-analytical sociology." The constant

\footnotetext{
${ }^{4}$ See the website of the so-called Akademie für Soziologie (Academy of Sociology), founded in opposition to the GSA in 2017: https://www.academy-sociology.net/the-academy/ goals-and-responsibilities/ (November 19, 2019). For further information about the Academy see the last chapter.
} 
refinement and mathematization of methods were considered an advancement and fostered "the (romantic or dogmatic) idea of a unified science" (Weischer 2004, p. 357, emphasis in original). Research that was not based on quantitative methods or that was even perhaps more theoretically oriented seemed irrational, pre-modern, and unworthy of being included in a unified science. Under these circumstances, the establishment of qualitative research was difficult and, accordingly, its successful institutionalization took a long time in Germany. It was not until 2003 that a separate section on qualitative social research could be established within the GSA.

According to the detailed analysis by Andrea Ploder (2018, p. 736), the development of qualitative research in post-World War II Germany was significantly influenced by two research traditions from the USA: Right after the war, the main resource was empirical social research in the tradition of Paul F. Lazarsfeld and Robert K. Merton. In the late 1960s and early 1970s, the German reception focused on so-called interpretive approaches in the tradition of the Chicago School, ethnomethodology, and sociolinguistics. Different interpretive approaches were combined with each other and with philosophical German traditions of phenomenology and hermeneutics, and inspired a number of novel traditions of qualitative research. In addition, other qualitative approaches like action research (Aktionsforschung), depth hermeneutics, and ethno-psychoanalysis were developed during this time (Ploder 2018, p. 736; for further details on action research see Kern 1982, pp. 246-272).

As Andrea Ploder (2018, pp. 744-745) has pointed out, four centers shaped the emerging field of qualitative research in Germany throughout the 1970s: In Frankfurt am Main, the group around Ulrich Oevermann ( $\left.{ }^{*} 1940\right)$ represented objective hermeneutics. Another center was formed in the 1970s by the "Working Group of Bielefeld Sociologists" around Joachim Matthes (1930-2009) and Fritz Schütze (*1944). In 1973, they published under the title "Alltagswissen, Interaktion und gesellschaftliche Wirklichkeit" (literally translated as "Everyday knowledge, interaction and social reality"), a widely read volume with translations of texts by American colleagues in the field of ethnomethodology, ethnotheory, and ethnography of communication (e.g., Herbert Blumer (1900-1987), Aaron 
Cicourel ( $\left.{ }^{*} 1928\right)$, Harold Garfinkel (1917-2011)). The third center was in Bonn, around Hans-Georg Soeffner (*1939), who later also taught in Konstanz as the successor of Luckmann. The fourth center was in Konstanz around Thomas Luckmann (1927-2016), who returned from the USA, and his phenomenologically oriented sociology of knowledge and sociology of language. Luckmann, a student and colleague of Alfred Schütz, had written the book The Social Construction of Reality with Peter L. Berger (1929-2017) in the USA in 1966. The book was published in German in 1969 and became one of the most widely read books in sociology. Many understood it not only as a new perspective for sociology, but also as a simple, easy-to-read introduction to sociology (cf. Tuma and Wilke 2018, p. 602). In Germany, Luckmann thus founded a Konstanz School, which today is dominant in the field of the sociology of knowledge and of qualitative, hermeneutical social research, and which has spread throughout the German-speaking world. In 1977, the exchange between these groups led to a joint section, "Sociology of Language," in the GSA, which was later renamed as "Sociology of Knowledge" section. Today it is the section of the GSA with nearly the most members. Numerous edited volumes and conferences followed, to which, among others, Anselm Strauss, Erving Goffman, and Aaron Cicourel were invited. In 1979, a working group on biographical research was established within the section.

The emerging women's and gender studies, too, contributed significantly to the establishment of qualitative research (cf. Ploder 2018, p. 750). The women's movement as a whole did not only focus on equal rights and participation, but strived for a complete "change of society" (Gerhard 2012, p. 110). Research was similarly oriented. In the 1970s, it was emphasized-prominently by the feminist Maria Mies- that research should be "emancipative," a "view from the bottom," and at the same time political, and it should "give women a voice of their own again" (Paulitz 2019, pp. 384-385).

\section{The Establishment of Women's Research AND GENDER STUdies}

Similar to other countries, in Germany too, research on gender and women's issues developed from the women's movement of the 1960s and 1970s, although there had been research by women and on women as well as on gender relations before that. Until the 1970s, however, most of this research had been conducted by individual female researchers (and 
sometimes also by male researchers-think, e.g., of Georg Simmel). But they often lacked a fundamental critique of patriarchal domination (cf. Paulitz 2019, pp. 380-382). ${ }^{5}$

Feminist sociological perspectives mainly developed from the women's movement. A central theoretical tool that was now being widely received was Simone de Beauvoir's book Le deuxième sexe (1949) (Paulitz 2019, p. 380). The main thesis of this book was: "One is not born, but rather, becomes a woman." De Beauvoir's book became a central theoretical tool for feminist sociology.

From the 1970s onwards, the criticism of the social situation of women became louder and a kind of "thought collective of feminism" emerged (Paulitz 2019, p. 382). The criticism did not only concern the mainstream of society. Also, the experiences of the marginalization of women during "1968" were a driving force (cf. Paulitz 2019, p. 383). In spite of Marxism, enlightenment, and emancipation, women had often been marginalized in this movement, too. The problems women addressed as well as their social preconditions either had been excluded from the discussions or were dismissed as so-called "side contradiction" (Paulitz 2019, p. 383), that is, as problems that would vanish into thin air if socialism were to become established.

The critique of gender discrimination affected most areas of society, including academia. Feminist scholars now demonstrated that science was not as gender-neutral as it claimed to be (cf. Paulitz 2019, p. 384). It was shown, for example, to what extent scientific statements, which at first glance appeared to be gender-neutral, were shaped by a male, "androcentric" gaze and permeated by patriarchal mechanisms of domination (Paulitz 2019, p. 384). They now reinterpreted the relationship between science and emancipative politics in such a way that feminist research was not limited to the established fields and institutions of science. Instead, they argued, science was to be employed and changed in such a way that it would serve the goals of feminist politics, that is, the goal of economic, political, social, and cultural equality. At the same time, research on women's issues also saw itself as an institutionalized form of self-reflection that allowed for the critical evaluation of the political practice of the women's movement (Hark 2005, p. 253).

\footnotetext{
${ }^{5}$ In the following, I mainly draw on Tanja Paulitz's (2019) historical reconstruction of feminist sociology in Germany and Sabine Hark's (2005) history of feminist discourse.
} 
As Tanja Paulitz (2019, p. 376) has pointed out, "in confrontation with and critical further development of different sociological ways of thinking, different paradigms of sociological engagement with gender were finally formed." Thus, there was not only one or "the" feminist perspective in sociology. Rather different theoretical perspectives on women and gender developed (Paulitz 2019, p. 376).

In the first phase of research on gender and women's issues, it was mainly the social inequality affecting women that was criticized. This research did not yet appear under the name of "gender studies," but was referred to as "research on women's issues". It focused "on women's perspectives and on women as key actors" (Paulitz 2019, p. 383). Initially research was limited to the structural discrimination of women. It opened up only slowly and became concerned with gender inequality more generally. Helge Pross (1927-1984), for example, a former assistant of Horkheimer and Adorno, who was one of the first female professors in sociology after 1945 (1965, she got a professorship at the University of Gießen, cf. Tegeler 2003, p. 224), showed in her empirical studies that the so-called "women's question" is always also a "men's question" (Tegeler 2003). ${ }^{6}$

As Sabine Hark (2005, p. 209) argues in her history of feminist discourse, the idea of women's studies was "ignited" at West German universities around 1973. Throughout the 1970s and early 1980s, women's studies focused on family, education, (house)work, the division of labor, and female careers. ${ }^{7}$ Carol Hagemann-White (*1942), for instance, who became a professor in Osnabrück in 1988, conducted research on violence, housework, education, and socialization (cf. Hagemann-White 1984, 2006). Others, such as Ilona Ostner (* 1947), Elisabeth Beck-Gernsheim (*1946), Gudrun-Axeli Knapp (*1944), or Regina Becker-Schmidt ( $\left.{ }^{*} 1937\right)$ studied employment, housework, and social policy (cf. Ostner 2006; Beck-Gernsheim 2006; Knapp 2006; Becker-Schmidt 2006). Also in the 1980s, a debate, in which, among others, Frigga Haug, Habermas, and Gertrud Nunner-Winkler $\left({ }^{*} 1941\right)$ were particularly involved, unfolded around Carol Gilligan's (*1936) thesis of a specifically female morality (Gilligan 1982; Habermas 1983; Haug 1984; Nunner-Winkler 1986).

\footnotetext{
${ }^{6}$ For the first generation of women who have achieved a professorship in the social sciences in Germany, see the autobiographical texts in Vogel (2006).

${ }^{7}$ For the following examples I mainly refer to Lucke (2003, p. 2).
} 
Some of these female researchers were related to one of the already mentioned sociological "schools," even if these relations were not uncritical. Ute Gerhard ( *1939), known among other things for her research on women, law, and the women's movement, attended lectures by René König (Gerhard 2006, p. 53). Becker-Schmidt was influenced by the early Critical Theory, especially by Adorno. Drawing on these influences and existing theoretical paradigms, they developed a genuinely independent branch of sociological thinking which understands itself not as a mere addon to general sociology (Becker-Schmidt 1987a). This also applies to sociologists like Irene Dölling (*1942) and Beate Krais (* 1944), who took up Pierre Bourdieu's research on masculine domination (Dölling 2006, p. 120; Dölling and Krais 1997; Krais 2000).

An important step toward the institutionalization of a feminist perspective in sociology was the founding of the section "Women's Studies in the Social Sciences" in the GSA in 1979. The section understood itself as a critical, "semi-autonomous corrective" (Paulitz 2019, p. 386). This means that the section was not concerned with adapting to the institutionalized discipline, but rather with its transformation-it was a matter of "dissident participation" (Hark 2005). In other words, the system was to be transformed from within. This led to both a "feminist turn of science" and an "academic turn of feminism" (Hark 2005, p. 10; emphasis in original). The institutional success of gender and women's research had to do with a generational change and the fact that, since the 1960s, more and more women had been able to start studying. Between 1970 and 1975, the proportion of female students rose from approximately $8 \%$ to $14 \%$; at the level of professors, the number doubled (Hark 2005, pp. 223-224), although their number still remained well below the number of male professors.

The pathways of the institutionalization of academic feminism were often contradictory and complex, but always highly self-reflexive. If it had been the merit of early research on women's issues to have initiated a fundamental change of paradigms and perspectives in the first place, deficits within this discourse were soon addressed. On the one hand, it was criticized that the demands for equality were still oriented toward the male mainstream. On the other hand, older approaches became more and more dominant that insisted on an essential difference between women and men. But even these were increasingly challenged, as the academic focus on the category "woman" neglected the differences between women (e.g., due to sexuality, class, and ethnicity). 
The 1980s brought about a crucial change: Instead of the category of "women," the categories of "gender" or "gender relations" increasingly became the primary focus of interest: "Characteristic of the Germanspeaking discussion is the emergence of relational approaches that moved the category of 'gender relations' into the center of attention and made gender a structural category" (Paulitz 2019, p. 389). This change of perspective, toward a focus on gender as a key social "structural category" (Beer 1984; Becker-Schmidt 1987b), led to an increased "sociologization of the feminist discourse" as well as to a "feminist re-reading and continuation of the sociological tradition" (Paulitz 2019, p. 389).

In the USA, the distinction between sex and gender had been fundamental since the 1970s. This distinction allowed for a differentiation between biological notions of sex and cultural notions of gender. In the 1980s it was considered to be an "intellectual common property of the feminist tradition of thought" (Paulitz 2019, p. 390). As already mentioned, the discussions in Germany dealt with the category "woman" in a similar vein, but initially this was done without the theoretical differentiation between sex and gender. Many discourses revolved more around the equality-difference debate (Gerhard et al. 1990; Maihofer 1997).

Gender was not yet seen as the key concept (cf. Paulitz 2019, p. 392); the central concept was rather the concept of "structure" (Paulitz 2019, p. 395), as especially Ursula Beer has pointed out (Beer 1984; 1990). Following Marxist theory in some point, feminism concentrated on the relations of gendered and capitalist structures, instead of problematizing primarily questions of identity. Gendered and capitalist structures, as pointed out, for example, by Becker-Schmidt (1987a), are "interdependent"; "gender and class-specific inequalities reinforce each other," and therefore women are subject to a "twofold societalization" (BeckerSchmidt 1987a). Social inequality is thus not the result of the supposed nature of women, but of "structural conditions" (Paulitz 2019, p. 393).

This perspective of feminist sociology, as it was developed in the 1980s, was indeed already a central step toward problematizing notions of a "natural" sex, toward "de-naturalization." Nevertheless, the discussions often still remained in a discourse that problematized neither the distinction between sex and gender nor the coupling of the category of gender to certain notions of reproduction, heterosexuality, and binary coding. This only happened in the 1990s with the publication and discussion of Judith Butler's Gender Trouble (1990), a book that also changed feminism in Germany considerably (cf. Hark 2005, pp. 269-332). I will come back to this in the last chapter. 


\section{Historical Self-Reflections in the Transition FROM THE 1970s TO THE 1980s}

The transition into the 1980s led to an important historical self-reflection of sociology in Germany. Around 1980, two special issues of the Kölner Zeitschrift für Soziologie und Sozialpsychologie (KZfSS, Cologne Journal of Sociology and Social Psychology) which dealt with the history of Germanspeaking sociology were published, which marked important steps in this process: Soziologie in Deutschland nach 1945 (Sociology in Germany after 1945) and Soziologie in Deutschland und Österreich von 1918-1945 (Sociology in Germany and Austria from 1918-1945). This process led to sometimes heated discussions, in which Schelsky (1981) and König (1987) were also involved. The controversy regarding the history of sociology developed particularly between Lepsius and König on the one side and Schelsky on the other. The dispute was about whether sociology in Germany had already come to its end before 1933, as Schelsky (1981, p. 15) claimed, or whether it was, on the contrary, very much alive toward the end of the Weimar Republic, but then brutally brought to a complete stand-still by the Nazi regime, as König (1987, pp. 343-387) and Lepsius (2017d, p. 86) argued. In the end, however, both represented a discontinuity thesis.

In 1981, Wolf Lepenies published four volumes on the history of sociology, which were internationally oriented. Also, Dirk Kaesler (1984) too did research on the very early phase of German sociology. He also has published several volumes on the classics of sociology since the mid-1970s, which are still used in teaching today. ${ }^{8}$ These historical studies of sociology at the beginning and during the 1980s were also an expression of the desire to bring order to the increasingly complex sociological field with the help of history, and to help the discipline to develop its own "identity" (Lepenies 1981). After the 1980s, there was a relative silence regarding the history of sociology. As we shall see, the study of the history of sociology gained more attention again only in the 1990s and then again after 2010 in discussions about the role of sociology during National Socialism. However, it was not until 2019 that a section on the history of sociology was established in the GSA.

\footnotetext{
${ }^{8}$ On the question of how some thinker becomes a classic of sociology, see Holzhauser (2021).
} 


\section{The Theory Boom of the 1980s}

In Europe there was a boom in sociological theories in the 1970s, but even more so in the 1980s, which Hans Joas and Wolfgang Knöbl (2009, p. 199) attribute to the fact that the relationship between sociology and philosophy was still closer there than it was in the USA. In Germany it was Jürgen Habermas and Niklas Luhmann who contributed to this "theory boom" in the early 1980s with two major sociological theories, which were already prepared in the 1970s. In 1981 Habermas published his seminal and widely discussed study Theorie des kommunikativen Handelns (The Theory of Communicative Action). The two volumes of the book were published in the same year in which Habermas resigned from his position as co-director of the Max Planck Institute (MPI) in Starnberg (cf. MüllerDoohm 2014, pp. 272-273; Leendertz 2010, p. 9; Leendertz 2018).9

The Theory of Communicative Action was both a novel theory of action and a sociological analysis of contemporary society. The theory of action aims at attributing a prominent role to the function of communicative understanding in social action. In contrast to instrumental or strategic action, communicative action is concerned with interaction, dialogue, and the domination-free development of consensus. Habermas' analysis of contemporary society comes down to the claim that the system, especially administration, economy and technology, and the elements of the system such as the monetary economy, bureaucracy, and success-oriented action, increasingly permeate the relationships and structures within the lifeworld. Habermas refers to this as a "colonization of the lifeworld by the system." Hence, Habermas combines crucial elements of systems theory with a theory of the lifeworld which is based on communicative action. Moreover, for Habermas, communicative action and deliberation also function as a normative standard in political and democratic theory.

However, Habermas not only shaped the theoretical debates in the 1980s with The Theory of Communicative Action. In addition, his commitment to the "project of modernity" was an important contribution. Habermas tried to defend this "project" against the discourse of postmodernism that emerged in the 1980s. He wrote against so-called critics of

\footnotetext{
${ }^{9}$ The resignation was the culmination of conflicts at the MPI in the wake of the retirement of Carl Friedrich von Weizsäcker (cf. Müller-Doohm 2014, pp. 268-270). The institute in Starnberg was finally dissolved. As its replacement, the Max Planck Institute for the Study of Societies in Cologne was established in 1984 under the management of Renate Mayntz (Leendertz 2010; Leendertz 2018).
} 
reason such as Adorno, Heidegger, and Georges Bataille (1897-1962), but also against postmodernism and the poststructuralists (Habermas 1985 ) and thus became a central actor in the international debates on modernity and postmodernism (cf. Moebius 2010). According to Habermas, the postmodernist critique of the "grand narratives" of progress, modernization, and rationalization ran the risk of renouncing practical critique of social conditions. Moreover, postmodernism also became entangled in a performative self-contradiction: After all, a radical critique of reason must itself argue rationally. The debates on postmodernism in the German-speaking sociological field continued into the 1990s and 2000s (cf. Neumeister 2000).

Until the 1990s, the controversies about the "project of modernity" dominated the image of Habermas as an intellectual. Habermas increasingly became one of the most important intellectuals in Germany and beyond. This was also apparent in his intellectual involvement in the Historikerstreit (historians' dispute) between 1986 and 1989. ${ }^{10}$ In the 1980s and 1990s, he increasingly produced publications on the philosophy of law and sociology of law as well as writings oriented toward concrete social processes in the fields of bioethics, religion, and European policy.

A further milestone of sociological theory in West Germany was the systems theory of Niklas Luhmann. At the beginning of the 1980s, Luhmann published papers on Social Structure and Semantics, in which he sociologically analyzed the historical change of concepts such as "culture," "state," "individual," and "nature." The highlight, however, was the book Soziale Systeme (Social Systems) from 1984. Soziale Systeme was the beginning of a series of analyses of individual functional systems, which Luhmann then presented from the end of the 1980s onwards and which, among other issues, dealt with the subsystems of economy, science, law, art, politics, religion, and media. In contrast to Habermas, Luhmann rarely spoke on current political issues. Despite, or perhaps because of, the rejection of politically intended real changes, systems theory initially became one of the most influential theoretical concepts in sociology in the 1990s. The journal Soziale Systeme, founded in 1995, also contributed to this

\footnotetext{
${ }^{10}$ The Historikerstreit was a public debate on the singularity of the Holocaust provoked by the conservative historian Ernst Nolte (cf. Piper 1987). Nolte saw the Holocaust as a reaction to the mass crimes in the Soviet Union. Habermas criticized the attempts to relativize the Holocaust and the crimes of the Nazi regime by making comparisons between different mass crimes against humanity using theories of totalitarianism.
} 
development. Habermas' theory, on the other hand, was increasingly received in political philosophy rather than in sociology (cf. Müller 2001, p. 44).

Even though with the theories of Habermas and Luhmann independent (West) German "grand theories" were available, West German sociology continued to deal with another major theory in the 1980s: with Parsons' theory synthesis. As elsewhere-consider Edward Shils, Shmuel Eisenstadt, Robert Bellah, and Jeffrey C. Alexander-a "renewal of Parsonianism" took place in West Germany too (Joas/Knöbl 2009, pp. 308-338). Richard Münch was a key player in this renewal. As early as 1976, Münch published two books, Theorie sozialer Systeme (Social Systems Theory) and Legitimität und politische Macht (Legitimacy and Political Power), in which Parsons played a prominent role. Several essays followed immediately after Parsons' death in 1979, in which Parsons' work was reconstructed and reinterpreted in the light of Kant and Weber. Münch's Theorie des Handelns. Zur Rekonstruktion der Beiträge von Talcott Parsons, Emile Durkheim und Max Weber (Action Theory: Towards a Reconstruction of the Contributions of Talcott Parsons, Emile Durkbeim and Max Weber), written in 1982, aimed at renewing Parsons' voluntarist theory of action. In the sociological field of the 1980s, Münch's book was perceived as a "competing product" to Habermas and as a demarcation to Luhmann. Luhmann did indeed follow Parsons in part. But in Luhmann's theory, the subsystems become independent to such an extent that each follows its own inherent logic, so that the different systems can only "irritate" each other. In contrast, Münch emphasized Parsons' theory of interpenetration, that is, the mutual influence of the subsystems. Furthermore, Münch criticized that in contrast to Parsons, neither Habermas nor Luhmann could explain the emergence of social order. Other books of Münch on the structure and culture of modernity followed. In recent years, Münch's interest has shifted to the theory of Pierre Bourdieu (1930-2002). Currently, Münch's $(2009,2014)$ critical analyses of the neoliberal reorganization of (higher) education and academia, that is, the economization of education, are of particular importance.

In contrast to the reception of Parsons, other theoretical concepts had a more lasting and vivid effect that is still observable today. This is true, for example, of (post-)structuralism, Michel Foucault (1926-1984), Pierre Bourdieu, the popular and media culture theories of the Birmingham 
Centre for Contemporary Cultural Studies (CCCS), ${ }^{11}$ as well as symbolic interactionism and American pragmatism, which Hans Joas in particular introduced in Germany and developed further in the 1990s into a theory of the Kreativität des Handelns (1992, The Creativity of Action 1997).

Already in the 1970s, René König had promoted the reception of the Durkheim School. Alfred Schütz and Norbert Elias were also perceived more widely in the 1980s. When the interest in Marx tended to decline, Elias' theory of the civilizing process (Elias 1977) seemed more "conciliatory" than Marxism, and advanced to a "refuge" and a "medium of survival of historical-materialist critique" (Rehberg 1979, p. 122). The reception of Elias, a student of Alfred Weber and Karl Mannheim, was at the same time an attempt to take up again the characteristic historical sociology of the Weimar period.

This revival of the German tradition of historical sociology, which was also associated with the name Max Weber, could be seen most clearly among the new cultural sociologists. Cultural sociology experienced a "renaissance" (Albrecht and Moebius 2014). This renaissance has to be understood not only against the background the general cultural turn in the humanities and social sciences and the massive cultural changes in Western countries since the 1970s, but also in the light of the theory boom. As mentioned, in the mid-1970s, Friedrich Tenbruck had encouraged the revival of a cultural sociology oriented toward Max Weber in order to oppose the dominant tendencies of Marxism and Parsonianism. In the mid-1980s, the section on "Cultural Sociology" was founded in the GSA. Inspired by Tenbruck, in this section, those sociologists found an institutional space who wanted to go beyond Marx, Parsons, Habermas, and Luhmann and to concentrate increasingly on pioneers such as Weber and Simmel, but also on Foucault, Elias, Bourdieu, philosophical anthropology, phenomenology, or historical sociology. The section considered itself to be an alternative to the "Sociological Theory" section of the GSA, which was founded around 1980 and in which the debate on the comparison of theories still continued. In particular, the "Cultural Sociology" section understood itself as an alternative to the dominant concepts of Parsons and sociobiology. With its references to philosophy and to the historical sociology of the 1920s, cultural sociology in Germany has developed a unique profile (cf. Moebius 2019) that goes further than a mere sociology

\footnotetext{
${ }^{11}$ In this context see also the combination of poststructuralism and cultural studies in the postcolonial studies.
} 
of culture and that does not exist in other countries and which also differs from American cultural sociology, which was shaped by Jeffrey C. Alexander (*1947) and draws mainly on Durkheim's later sociology of religion.

It was in the 1980s, too, that the reception of Pierre Bourdieu intensified (cf. Rehbein 2018). Today, alongside Weber and Marx, he is one of the best-known and "most received authors among students of sociology in Germany" (Schneikert et al. 2019). Here, too, one is faced with a "grand theory." However, unlike Habermas or Luhmann, Bourdieu developed his theoretical notions and concepts in close connection with empirical research, using both qualitative and quantitative methods. Furthermore, Bourdieu is one of the few sociologists who have reflected sociologically on the emergence of their respective sociology (Bourdieu 2002). Books by Bourdieu had already appeared in German in the 1970s (e.g. Bourdieu and Passeron 1971). There were also already links to Bourdieu in the sociology of education. However, it was above all his book La distinction. Critique sociale du jugement (Distinction. A Social Critique of the Judgement of Taste) published in 1979 and translated into German in 1982, that attracted enormous attention and interest. Bourdieu's books were then successively translated into German and his theory has been widely received to this day. The reception of Bourdieu's work in Germany (similar to that in other countries) became more and more differentiated, so that today, in addition to sociological theory, his work has an impact on almost all sociological subfields. Research on social structure analysis, milieus, lifestyles, and inequality research refer to Bourdieu just as studies in the sociology of education, of gender, of culture, of language, and of intellectuals.

Bourdieu's great success was also related to the social problems facing West German society. In contrast to Anthony Giddens ( ${ }^{*} 1938$ ) or Ulrich Beck (1944-2015), for example, who supported the so-called Third Way of Social Democracy of Tony Blair and Gerhard Schröder, Bourdieu's theory provided a fundamental critique of the conditions of contemporary society and saw itself as a committed sociology, which, in view of the major problems such as unemployment, social exclusion, precarization, and economization of the social, in a way suggested itself.

Bourdieu's sociology was part of a larger theoretical movement that could be observed internationally in the 1980s: the overcoming of the micro-macro dualism (see Alexander 1988). In other words, the social was understood and explained neither primarily on the basis of individual 
actions nor exclusively by structures and systems. Instead, action and structure were seen as being closely intertwined.

Other theories could also be found in the sociological field in West Germany in the 1980s. In close connection to quantitative social research were rational choice theories. Since the end of the 1980s, the individualistic theory program has become more differentiated. Since then it has been possible to distinguish clearly between approaches and actors of rational choice theories and those of "explanatory sociology" (Maurer 2019, p. 300). Here it was Rolf Ziegler (*1936), Karl-Dieter Opp (*1937), Günter Büschges (1926-2017), and later especially Hartmut Esser (*1943), who, from the 1980s onwards, starting from Cologne, developed the "model of sociological explanation." In doing so, they set themselves apart from simple rational choice theories. "Explanatory sociology" was based on a close connection between critical rationalism, rational choice, the analysis of objective structures, Max Weber's theory of action, and the analysis of institutions (Maurer 2017, pp. 15-33). Important impulses came from James Coleman (1926-1995), Raymond Boudon (1934-2013), and Siegwart Lindenberg ( $\left.{ }^{*} 1941\right)$. Today there are close connections to network research (Harrison White (*1930), Mike Granovetter ( $\left.{ }^{*} 1943\right)$ ), neo-institutionalism, actor-centered institutionalism (Renate Mayntz, Fritz Scharpf), analytical sociology, and sociology of social mechanisms (Peter Hedström $\left({ }^{*} 1955\right)$, Peter Bearman $\left.(* 1956)\right)$.

As can be seen from the diverse theories, the related theoretical debates, and the institutional differentiation into different sections, a "pluralization of perspectives" (Borggräfe 2018, p. 883) developed in the sociological field in the 1980s, which made the unity of sociology that some had hoped for impossible. On the one hand, this was due to the increasing complexity of society, but on the other hand, it also resulted from internal disciplinary processes, especially the multiplication of positionings in the sociological field. A further indication of the complexity, specialization, and increasing pressure to establish a position of one's own in the field is the growing trend away from overarching, large-scale sociological theories toward rapidly changing analyses of contemporary society that can be observed since the mid-1980s (cf. Osrecki 2018). ${ }^{12}$

\footnotetext{
${ }^{12}$ The genre of the soziologische Zeitdiagnose (sociological analysis of contemporary society) was previously present in the German-speaking world, especially in the historical sociology of the interwar period (Alfred Weber, Werner Sombart, Franz Oppenheimer, and Karl
} 
In 1986, Ulrich Beck made a much-noticed beginning to this sociological trend with his book Risikogesellschaft. Auf dem Weg in eine andere Moderne (Risk Society. Towards a New Modernity, published in English in 1992). The success of the book was greatly facilitated by the fact that it was printed shortly before the nuclear accident in Chernobyl on April 26, 1986. Beck's diagnosis of large-scale technological risks coincided exactly with the critique of technology and skepticism about progress of the environmental and anti-nuclear movements, which were growing in the 1980s. Beck had actually written the book as a diagnosis of the future, but instead it had become a direct analysis of the present. The central argument of Risk Society was that modern societies are increasingly faced with self-produced, transnational risks (nuclear power, forest dieback, terrorism, etc.) that potentially affect all population groups. Thus, technical and economic "progress," which was initially interpreted as a gain in power, also has a downside: the production and redistribution of risks. The progressive processes initiated by modern society and their secondary consequences fall back on the society as problems. The uncertainty that this brings about is intensified by processes of individualization that radically change class affiliation, religious and political commitments, work processes, and family relationships. At the end of the book, Beck sketched the first outlines of what was systematically elaborated further in the 1990 s as the "theory of reflexive modernization."

\section{Processes of Differentiation and Pluralization In the Face of Social Change}

It was not only the field of sociological theory that was characterized by processes and dynamics of differentiation and pluralization in the 1980s. Rather, the entire sociological field was characterized by this. It was oriented toward increasingly specific fields of social practice and toward new problems (Weischer 2004, p. 376), which were closely related to social change in Germany: Like many other Western countries, Germany, too, was transformed from an industrial society to a post-industrial service society (Schildt 2007 , p. 56), sometimes referred to as the "knowledge society" or "information society." This change was driven by technological change and the transformation of media and it was

Mannheim) and played a rather marginal role from 1945 to 1986 - with the exception of the works of Helmut Schelsky. 
intimately linked to processes of globalization that took place in the sphere of economics, politics, and culture. ${ }^{13}$ In the USA and in Western Europe, economic neoliberalism triumphed and many areas of society were "economized." This "economization" also affected sociology. In his analysis of the history of empirical social research in Germany, Weischer (2004, p. 371) describes this as a veritable "economization of sociology," which was demonstrated by the fact that economic patterns of interpretation and rational choice theories became increasingly important within the sociological field and a certain fetishism of third-party funding (cf. Münch 2014) also spread there.

The continuing rationalization and technical progress led to major changes in industrial production. New forms of work emerged. Debates about the "end of the division of labor" (Kern and Schumann 1984) and the effects of technical rationalization dominated discussions, for example, in the field of industrial sociology and the sociology of work. In Germany, the economy recovered in the 1980s from the crises of the 1970s. In particular, the traditional industries such as the automotive industry and chemical industry boomed. At the same time, there was rising mass unemployment (cf. Abelshauser 2011, p. 470), which did not disappear as a result of the boom, since the economic profits were often no longer reinvested in industry, but were used as "speculative funds on the financial markets" (Fülberth 2012, p. 72).

In the early 1980s social democracy in Germany fell into a crisis, when in 1982 Helmut Kohl of the CDU became the new Chancellor. The power of the trade unions was diminished (cf. Fülberth 2012, p. 73). Unemployment and poverty grew, intensified by the neoliberal dismantling of the welfare state. These tendencies were intensified after reunification, especially in East Germany. These ongoing developments continue to shape the discourses on precarity and right-wing extremism to this day. Currently, sociologists characterize German society as a "society of decline" (Nachtwey 2016).

The Cold War entered a hot phase in the early 1980s. During Ronald Reagan's first term as president of the USA, a massive rearmament program began. As reaction, the peace movement grew stronger. In the mid-1980s, the Cold War took a radical turn when Reagan and Soviet party leader Mikhail Gorbachev sought to end the arms race.

\footnotetext{
${ }^{13}$ For the historical processes here described see Wolfrum (2007b).
} 
Other new social movements such as the environmental movement also became stronger. The peace and environmental movements gave rise to the Green Party in 1980. The ecological awareness of the Germans grew, fueled by the "forest dieback," the environmental risks of industry, and by the Chernobyl disaster.

In the cultural sphere, besides the discourses on postmodernism in art, literature, architecture, and science, what was then seen as new media and technologies were particularly influential in the 1980s. Since the mid-1980s, numerous private broadcasting stations have been established. In the field of music, punk and pop were dominant in that era.

As a reaction to these processes, sociology also turned to new topics: Industrial society and service society, unemployment, poverty, mass communication, cultural change (postmaterialism, postmodernism), environmental problems, migration, urban life, gender, individualization, life courses, social change, and social milieus were the major topics of sociological research in the 1980s, which also attests to the increasing differentiation of the sociological field-both institutionally and with regard to its subject matter. This differentiation was, then again, the subject of the perception of an "identity crisis" (Beck 1982, p. 6). There were fears that sociology could "dissolve itself" in the course of parceling out specific fields of problems (Beck 1982, p. 7). The atmosphere of crisis was intensified by the fact that the number of sociology students stagnated in the 1980s (Stockmann 2002, p. 239) and the number of sociological staff at the universities decreased (Lamnek 1991, p. 715).

As the discourse on identity and postmodernism made clear, the belief that sociology would facilitate progress and plannability diminished ever more. Doubts regarding the potential of sociology and its practical application arose. These doubts led to numerous debates on the relationship between theory and practice (Neun 2016) and to reflections on the utilization of sociological knowledge (Beck 1974; Beck 1982; Beck and Bonß 1989). These controversies were influenced by American discussions from the 1960s (cf. Neun 2016, p. 335). In retrospect, they appear to be an early step in the direction of current discussions about "public sociology" in Germany.

As far as social research is concerned, the 1980s marked the end of its growth and heyday. Sociology and social research had successfully established and institutionalized themselves in Germany. As contemporaries noted, the social sciences had become a "normal science" (Weischer 
2004 , p. 375). At times, sociology was so successful that sociological knowledge had become common knowledge or was widely received in other academic disciplines. The downside of this, however, was that a broad sociologization and expansion up to the everyday use of sociological terms simultaneously threatened the status of sociology as an independent discipline (cf. Weischer 2004, p. 377; Moebius 2009).

Everything changed after 1989: The collapse of the Eastern Bloc, the fall of the Berlin Wall, and the German reunification led to massive ruptures and great transformations in sociology in both Germanies. In addition, a generational change took place. The sociologists born before 1930 retired. As Lepsius (2017h, p. 367) showed, 25\% of the 400 professorial positions had to be filled. This also contributed to the great transformation of sociology in the 1990s.

Open Access This chapter is licensed under the terms of the Creative Commons Attribution 4.0 International License (http://creativecommons.org/licenses/ by $/ 4.0 /)$, which permits use, sharing, adaptation, distribution and reproduction in any medium or format, as long as you give appropriate credit to the original author(s) and the source, provide a link to the Creative Commons licence and indicate if changes were made.

The images or other third party material in this chapter are included in the chapter's Creative Commons licence, unless indicated otherwise in a credit line to the material. If material is not included in the chapter's Creative Commons licence and your intended use is not permitted by statutory regulation or exceeds the permitted use, you will need to obtain permission directly from the copyright holder.

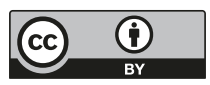

